\title{
Correction to: Post-treatment benign changes versus recurrence in non-lymphoid head and neck malignancies: can diffusion- weighted magnetic resonance imaging end up the diagnostic challenge?
}

Dalia K. Serour ${ }^{1 *}$, Khaled M. Adel ${ }^{1}$ and Ayman M. A. Osman ${ }^{2}$

\author{
Correction to: Egypt J Radiol Nucl Med (2020) 51:56 \\ https://doi.org/10.1186/s43055-020-00177-3
}

Following publication of the original article [1], the author reported that the institution Cairo University Hospitals (Cairo, Egypt) is not added in the Methods section. In this correction article the affected part of the article is shown.

1. In the correction article the name of the institution is added in the following wording;

"Thirty consecutive adult patients who underwent treatment for non-lymphoid head and neck malignancies (surgery, chemoradiation or combined surgery and chemo/ radiotherapy) in Cairo University Hospitals (Cairo, Egypt) between October 2018 and October 2019, then each of whom developed a suspicious lesion on post-treatment MRI scans at the primary site of the previously treated tumour, were enrolled into the study".

\section{Author details}

'Department of Diagnostic and Interventional Radiology, Faculty of Medicine, Cairo University, Cairo 11562, Egypt. ${ }^{2}$ Department of General Surgery, Faculty of Medicine, Cairo University, Cairo 11562, Egypt.
Published online: 23 April 2020

\section{Reference}

1. Serour DK et al (2020) Post-treatment benign changes versus recurrence in non-lymphoid head and neck malignancies: can diffusion-weighted magnetic resonance imaging end up the diagnostic challenge? Egypt J Radiol Nucl Med 51:56. https://doi.org/10.1186/s43055-020-00177-3

* Correspondence: daliakhaled80@yahoo.com

'Department of Diagnostic and Interventional Radiology, Faculty of

Medicine, Cairo University, Cairo 11562, Egypt

Full list of author information is available at the end of the article

Springer Open

(c) The Author(s). 2020 Open Access This article is licensed under a Creative Commons Attribution 4.0 International License, which permits use, sharing, adaptation, distribution and reproduction in any medium or format, as long as you give appropriate credit to the original author(s) and the source, provide a link to the Creative Commons licence, and indicate if changes were made. The images or other third party material in this article are included in the article's Creative Commons licence, unless indicated otherwise in a credit line to the material. If material is not included in the article's Creative Commons licence and your intended use is not permitted by statutory regulation or exceeds the permitted use, you will need to obtain permission directly from the copyright holder. To view a copy of this licence, visit http://creativecommons.org/licenses/by/4.0/. 